\title{
Making Devolution Work in Pakistan
}

\section{Aisha Ghaus-Pasha*}

\begin{abstract}
This article discusses how the $7^{\text {th }}$ National Finance Commission award and the $18^{\text {th }}$ Amendment to the Constitution have strengthened the autonomy of the federating units in Pakistan. The former has empowered the provinces by increasing their access to financial resources, but there is the danger that it may increase the consolidated fiscal deficit unless both the federal and provincial governments increase their fiscal efforts and rationalize their expenditures. The 18 th Amendment has the potential to change the structure of governance, but has been implemented in such a way that effective decentralization has been at least partially rolled back. For devolution to work in Pakistan, financing and the delivery of devolved services will have to be more effectively organized and managed.
\end{abstract}

Keywords: Fiscal, devolution, $18^{\text {th }}$ amendment, Pakistan.

JEL classification: $\mathrm{O} 16$.

\section{Introduction}

The years 2009 and 2010 will be remembered by Pakistanis because the country witnessed two significant developments in the process of fiscal devolution. The first was the announcement of the $7^{\text {th }}$ National Finance Commission (NFC) award, which was agreed on in December 2009. The second was the Parliament's unanimous ratification of the $18^{\text {th }}$ Amendment to the Constitution in April 2010. Together, these developments have the potential to fundamentally restructure governance in Pakistan.

Intergovernment revenue transfers, which are the lifeline of provincial governments (accounting for 80-90 percent of provincial revenues), take place according to the provisions of the NFC awards. The tenure of the NFC award, according to constitutional provisions, is five years and the award determines the contours of the provincial mediumterm financial outlook. Principally, the 7th NFC Award enhanced the share of provincial governments in the divisible pool of taxes, thereby substantially improving their fiscal position.

\footnotetext{
* Professor, Beaconhouse National University (BNU), Lahore, and Director, Institute of Public Policy, BNU, Lahore.
} 
The 18th Amendment, on the other hand, has altered the functional responsibilities of different levels of government. It has abolished the Constitution's concurrent legislative list and changed the federal legislative list (Parts I and II). With the major exception of electricity, the concurrent list's functions have been devolved to the provinces. The amendment has also transferred certain subjects from Part I of the federal legislative listcomprising those functions allocated exclusively to the federal government-to Part II, making them a joint provincial-federal responsibility under the Council of Common Interests (CCI). Consequently, under the 18th Amendment, there is undoubtedly a more balanced distribution of functions between the federal and provincial governments, thereby greatly empowering the latter.

Two years have passed since the NFC award became operative and one year following the implementation of the $18^{\text {th }}$ Amendment. The question that arises is whether fiscal devolution is working in Pakistan and if not, can it be made more effective? We address both these questions in this article. Section 2 briefly describes the 7th NFC award, and Section 3 analyses some emerging issues in the aftermath of the award. Section 4 describes the $18^{\text {th }}$ Amendment and assesses its efficacy. Section 5 discusses the financing of devolved services, while Section 6 identifies emerging issues in the delivery of devolved services and the strengthening, planning, and execution of projects. Finally, Section 7 presents some key conclusions.

\section{The $7^{\text {th }}$ NFC Award}

The $7^{\text {th }}$ NFC award has significant fiscal implications. Intergovernment transfers from the federal to the provincial governments take place according to the provisions of the NFC awards. These have historically taken three forms: (i) "divisible pool" transfers, (ii) straight transfers, and (iii) grants and subventions.

The $7^{\text {th }}$ NFC, reconstituted by the President of Pakistan on $24^{\text {th }}$ July 2009 held six meetings before reaching a consensus on the vertical and horizontal sharing of the divisible pool. The award is unique in its design and sensitivity to the needs of the federating units. Its key salient features are described below:

- Enlarged divisible pool. The size of the divisible pool has been enhanced because of a reduction in collection charges from an average of 5.2 percent to 1 percent. 
- Provincial sales tax on services. The NFC recognized that sales tax on services is a provincial subject and accepted the provinces' demand for services taxed within the ambit of federal excise duties to be devolved to the latter. There is provision for general sales tax on services to be collected by the provinces, if they so desire.

- Larger provincial share in vertical transfers. The award has increased the provincial share to 56 percent in the first year and 57.5 percent in subsequent years. The award has also eliminated the existing system of subventions-for which the derivation of the distribution formula is not known-and replaced it with fiscal equalization among the provinces through a nondiscretionary, transparent revenue-sharing formula (discussed below). The only exception is a PKR 6 billion grant to Sindh.

- Diversified bases for horizontal transfers. Punjab has accommodated the other provinces' longstanding demand for multiple indicators for horizontal distribution. Previously, the divisible pool (excluding one sixteenth of sales taxes) was distributed on the basis of population. The distribution of one sixth of sales taxes, in lieu of the octroi/zila taxes transferred to the district governments, occurred on the basis of collection shares determined by the 1996 revenue-sharing arrangements. Accordingly, Punjab received a share of 50 percent; Sindh, 34.85 percent; Khyber-Pakhtunkhwa (KP), 9.93 percent; and Balochistan, 5.22 percent. This distribution arrangement, however, remains disputable.

Under the 7th NFC award, all revenue will be distributed according to the provincial shares that have been agreed on-derived using the multiple criteria of poverty, inverse population density, revenue contribution (both collection and proxy generation), and, of course, population. The formula builds in horizontal fiscal equalization by explicitly recognizing backwardness (poverty) and the cost of provision differentials (inverse population density) while allowing provinces some benefit of the revenues collected and generated. Population, however, continues to be the principal basis of distribution, with a weight of 82 percent.

- Special province-specific considerations. The award is also unique in that it takes into account special considerations that impact the fiscal requirements of the provinces. First, the federal government and provinces have recognized $\mathrm{KP}^{\prime} \mathrm{s}$ role as a frontline province in the 'war against terror'. The federal government has undertaken to bear 
all expenditures incurred by the war. As a gesture of support, the other provinces have joined the federal government and earmarked 1 percent of the total divisible pool for KP.

Second, both the federation and provinces have recognized the special development needs of Balochistan, and agreed to not only raise the latter's share of the provincial divisible pool to 9.01 percent, but also to underwrite revenue transfers of PKR 83 billion to the province. The federal government will make up any shortfall in this amount from its own resources. Punjab will contribute the largest share by accepting a cut of 1.27 percent in its share, followed by Sindh ( 0.39 percent), and $\mathrm{KP}(0.26$ percent).

- Enhancement in straight transfers. Royalties on natural gas and gas development surcharges (GDS) have been notionally clubbed under one head; the rate per mmBTU will be worked out. Royalties will be distributed on the existing basis while the GDS will be distributed by making adjustments based on this effective rate. Consequently, the share of Balochistan and Punjab will go up at the expense of Sindh. The federal government has also resolved the longstanding dispute with KP on the arrears of hydel electricity profits and with Balochistan on the arrears of GDS. According to the agreement, KP will receive arrears of PKR 110 billion over five years, while Balochistan will receive PKR 10 billion over the same period.

The budgeted increase in revenue transfers to the provinces in the first year after the implementation of the award is presented in Table 1. These are budgeted to be higher by PKR 222 billion in 2010/11 because of the 7 th NFC award. In other words, transfers would have been over 27 percent lower had revenue sharing in 2010/11 continued according to the previous arrangements.

Table 1: Budgeted increase in revenue transfer to provinces under $7^{\text {th }}$ NFC award (PKR billion)

\begin{tabular}{lc}
\hline Transfer to provinces & 2010/11 (RE) \\
\hline Under previous revenue-sharing arrangements & 783.0 \\
(ad-hoc presidential order) & \\
Under 7th NFC award & 997.7 \\
Increase & 214.7 \\
Percentage increase & 27.3 \\
\hline
\end{tabular}




\section{Emerging Issues in the Aftermath of the NFC Award}

The $7^{\text {th }}$ NFC award has significantly changed the status quo and is, therefore, likely to have substantial and varying implications both for the federal government and the four provincial governments. Some of the consequences of the award have become apparent. H. A. Pasha, Pasha, and Imran (in press) have developed a framework to analyze some of the behavioral implications of the award. Among their key findings is that larger provincial transfers have tended to enhance the federal government's fiscal efforts. However, strong downward rigidities with respect to expenditures on debt servicing, defense, and general administration have meant that the federal government is unable to cut back current expenditures. Consequently, there is a lagged downward adjustment in federal development expenditures to the availability of resources, which implies that the federal Public Sector Development Program (PSDP) will take some time to reduce to the desired size, given the fall in growth of net revenue receipts.

With regard to the provincial governments, Pasha et al. (in press) conclude that the provinces are inclined to slacken their fiscal efforts in the event of a favorable award, such as the latest dispensation. Their current expenditures appear to respond quickly and strongly to larger transfers, and their annual development programs (ADPs) appear to be linked to the size of the revenue surplus, which is likely to be larger when transfers increase. However, there is a process of lagged adjustment, indicating - especially in the case of the smaller provincial governments-that there are short-run limits to absorption capacity in the implementation of a larger portfolio of projects. This may, therefore, lead to some fiscal surplus in the short run.

In line with the results of their empirical analysis, the first two years following the implementation of the $7^{\text {th }}$ NFC award were marked by a rise in the consolidated fiscal deficit. This is because (i) there has been no corresponding cutback in federal current expenditure, (ii) the reduction in size of the PSDP was accomplished with a time lag, and (iii) provincial current expenditure increased rapidly in response to larger transfers. This impact has been somewhat moderated by the launching of a more intensive fiscal effort through tax reforms by the federal government. This, at least partially, makes up for the loss in net revenue receipts while provincial ADPs take some time to fully adjust upward. The net impact on the overall fiscal deficit of the award has been estimated at PKR 48 billion in 2010/11, i.e., the fiscal deficit was 0.3 percent of GDP higher than it would have been in the absence of the award. 
To sum up, while the 7th NFC award represents a level of fiscal decentralization that may be viewed as a great "opportunity" for the provinces to improve their residents' wellbeing, it has been created by the federal government at some cost to the latter's own finances. Therefore, it is essential that this "opportunity" is translated into welfare gains and not wasted. For this to be achieved, the onus is on the four provincial governments. It is important that, given the larger transfers from the federal government, the provinces do not, first, slacken their own fiscal efforts and that additional transfers should essentially supplement and not substitute for provinces' own revenues.

Second, the provinces must avoid profligate, nonproductive expenditures. A prudent spending strategy is an important prerequisite if the "opportunity" that the 7th NFC award has opened up is to be realized. Additional resources should be used increasingly for development and the repair and maintenance of infrastructure. Moreover, these resources should be routed largely toward backward regions and pro-poor sectors.

Third, provinces should develop medium-term development frameworks, taking into account the additional funding available. These will help the provinces strategize and prioritize their development needs and channel their spending accordingly.

The $7^{\text {th }}$ NFC award also has significant implications for the federal government. The structural deficit has to be brought down-federal nonproductive current expenditures must be cut back. Sharper prioritization of the federal PSDP is essential. Considering that the focus for development has shifted largely to the provinces, federal-level development programs must be pruned. Finally, the linchpin of the strategy to keep the federal fiscal position sustainable is to enhance the level of resource mobilization. The country is stuck at a tax-to-GDP ratio of less than 10 percent, even when in real terms the tax bases have grown in excess of 7 percent. In fact, the tax-to-GDP ratio has shown a tendency to decline in recent years. A strategy to mobilize resources has to focus on broadening tax bases and improving tax administration.

\section{The $18^{\text {th }}$ Amendment}

The devolution process under the $18^{\text {th }}$ Amendment was undertaken in three phases. In the first phase, the ministries for special initiatives, zakat and ushr, youth affairs, population welfare, and local government and rural development were devolved. The second phase was completed in 
April 2011, devolving the ministries for education, social welfare and special welfare, livestock and dairy development, and culture and tourism. The remaining seven divisions of food and agriculture, health, labor, women's development and manpower, sports, environment, and minorities' affairs were devolved in the third phase.

Overall, the size of the federal secretariat was reduced by 15 ministries/17 federal divisions, bringing down the number of federal divisions from 50 to 33 . To facilitate the implementation of the devolution process, the federal government established the Implementation Commission, comprising eight members from different political parties, which functioned till 30th June 2011. The provincial governments formed their own committees, comprising the political leadership and members of the bureaucracy to determine strategies to absorb the devolved subjects.

Besides the allocation of functional responsibilities, the $18^{\text {th }}$ Amendment has also made changes to the special provisions of the Constitution, in the finance, audit and borrowing powers clauses. A key change relates to the composition and functioning of the CCI, which the amendment has greatly strengthened. Very importantly, the provinces have been given borrowing powers (see Section 5).

Table 2 shows that, as of the 2010/11 base of expenditures, the provincial governments' expenditure liability under the $18^{\text {th }}$ Amendment is PKR 87 billion. Overall, the implied enhancement in the size of the provincial budgets to accommodate the additional functions is about 7 percent. It is somewhat higher for Sindh and Punjab and lower for KP and Balochistan.

Table 2: Impact of costs of transferred functions on provinces

\begin{tabular}{lrcc}
\hline & \multicolumn{3}{c}{$\begin{array}{c}\text { Cost of transferred } \\
\text { functions }\end{array}$} \\
Four provinces combined & \multicolumn{2}{c|}{ (PKR billion) } & Percentage \\
\hline Current expenditure & 891.7 & $45.6^{\mathrm{a}}$ & 5.0 \\
Development expenditure & 296.0 & 41.6 & 15.7 \\
Total expenditure & $1,187.7$ & 87.2 & 7.3 \\
\hline
\end{tabular}

a On the assumption that there is no change in expenditure.

Has the $18^{\text {th }}$ Amendment made this kind of difference, i.e., savings in the federal budget and expansions in the provincial budgets? The answer is influenced by a number of implementation decisions made by 
the $\mathrm{CCI}$ and the political economy pressures binding on the federal government. The CCI's key decisions with financial implications include the following.

- Federal employees of the devolved ministries/divisions will be retained at the federal level. Only employees working in the provinces will be taken over by the provincial governments.

- The federal government will provide funding for vertical programs in population welfare and health for the period of the current NFC award, up to $2014 / 15$.

- The provinces will finance the development projects of the devolved ministries that have been transferred to them, and is at liberty to continue or abandon these projects. The federal government will continue to fund projects/schemes undertaken on the prime minister's/president's directives.

- The Higher Education Commission (HEC) will continue to operate at the federal level till such time as the HEC Act is amended, as per a Supreme Court decision. The federal government will fund expenditure on universities during the tenure of the current NFC award.

Pasha and Pasha (2012) conclude that the federal budget for 2011/12 - the first post-18 ${ }^{\text {th }}$ Amendment budget-does not exhibit much in the way of savings in the federal PSDP arising from the amendment, while there is some increase in current expenditure. The principal reason for this is that, while there is no federal PSDP allocation for the ministries/divisions to be devolved, political expediency has impeded the implementation of the amendment as the ruling coalition does not have enough ministerial portfolios for its partners. We see the appearance of nine new ministries/divisions: (i) the Ministry of Human Rights, (ii) Ministry of Inter-Provincial Coordination, (iii) Ministry of Human Resources Development, (iv) Ministry of National Harmony, (v) Ministry of National Heritage and Integration, (vi) Ministry of National Regulation and Services, (vii) Ministry of National Food Security and Research, (viii) Ministry of Professional and Technical Training, and (ix) Ministry of National Disaster Management. Allocations have also been made for two new divisions, the Capital Administration and Development Division and the Inter-Provincial Coordination Division, both of which have been created as a consequence of the $18^{\text {th }}$ Amendment. The latter will effectively act as a secretariat for the CCI. 
As far as the funding of devolved subjects is concerned, the provincial budgets for 2011/12 contain limited provisions both for current and development expenditure. Punjab, for example, has allocated PKR 410 million (compared to PKR 7.8 billion as originally envisaged) to meet the current expenditure needs of the offices devolved to its government through the Schedule of New Expenditure and supplementary grants. On the development side, Punjab has allocated PKR 0.5 billion for 30 projects adopted in its ADP for 2011/12. Sindh has allocated a lump sum of PKR 3 billion for all costs of devolution. KP has allocated PKR 0.4 billion for current expenditure and PKR 3 billion for the development projects devolved to the province. Given the way in which the $18^{\text {th }}$ Amendment has been implemented, its financial implications for the provincial governments have been hugely minimized.

While both the $7^{\text {th }}$ NFC award and the $18^{\text {th }}$ Amendment have strengthened the autonomy of the federating units, the former stands in danger of increasing the consolidated fiscal deficit. Meanwhile, the implementation of the latter-with subjects being retained and relocated, and some that continue to be federally funded-has meant that effective decentralization has been effectively postponed.

The next section presents some thoughts on making devolution in Pakistan work, beginning with financing issues, followed by emerging issues on services delivery, planning, and execution.

\section{Financing the Devolved Functions}

As mentioned earlier, the federal government will only transfer funding responsibility for the additional expenditure liabilities after the end of $7^{\text {th }}$ NFC award tenure. This arrangement was necessary because the award preceded the $18^{\text {th }}$ Amendment and so reflected the allocation of functions at the time. There are two possibilities regarding the new revenue-sharing system once the award's tenure has ended. First, the provinces' share in vertical transfers may be enhanced in line with their additional expenditure needs. An indicative increase in the vertical share can be derived by looking at the expenditures presently incurred by the provincial governments on subjects devolved under the $18^{\text {th }}$ Amendment, with, of course, built-in growth provisions.

Second, Article 172(3), while providing for equal federal and provincial ownership of minerals, also implies that the income from these natural resources will be shared on a 50:50 basis. Essentially, the nontax 
receipts of dividends and profits of corporations such as the Oil and Gas Development Corporation (OGDC) may have to be shared between the federal and provincial governments. If they agree on a sharing formula, then the additional funding requirements of the 18th Amendment can be partially financed through these nontax revenue sources. Initial estimates indicate that such funding could contribute about PKR 17 billion annually to the four provincial exchequers combined. Clearly, this arrangement would favor the natural resource-rich provinces, Sindh and Balochistan.

Along with larger federal transfers, it is very important that the new revenue-sharing arrangements provide incentive for greater fiscal effort on the part of the provinces. Pasha et al. (in press) use an analytical framework to conclude that a matching grant linked to an increase in self-financed expenditure would reduce the negative effects of an increase in transfers following an award. Such a scheme could be put in place as part of the NFC award. Additionally, research shows that the development of provincial taxes on agriculture, real estate, and services could yield additional revenue of up to 0.8 percent of the GDP, equivalent to almost PKR 126 billion on the current tax base.

Over and above these sources, the provinces will also have to enhance their levels of cost recovery, particularly in economic and community services, and strengthen tax administration. The $11^{\text {th }}$ Finance Commission of India has incorporated similar incentives with a view to providing better financial management and greater fiscal discipline (7.5 percent of states' revenues is to be shared on the basis of the measure of financial discipline corresponding to the change in the ratio of own revenue receipts to total revenue expenditure).

The new intergovernment fiscal arrangements will also have to mark a limit to provinces' borrowing powers. Provincial debt levels have not featured in discussions on debt sustainability in Pakistan because of the perception that these governments face a "hard budget constraint" due to constitutional limitations on their borrowing, prior to the $18^{\text {th }}$ Amendment. Prior to the 1996 NFC award, the federal government made cash development loans to the provincial governments, but this practice has largely been discontinued because of complaints by the latter that the markup rate was too high. Earlier, the provinces used to float long-term bonds in the capital market, but this practice, too, has largely ceased.

As of end-June 2010, the total provincial debt stands at close to PKR 800 billion, equivalent to about 5 percent of GDP. The bulk of this debt, 77 
percent, is foreign debt. Punjab has a share of 61 percent, followed by KP (17 percent), Sindh (13 percent), and Balochistan (9 percent). The burden of interest payments as a percentage of revenue receipts ranges from 2 to 5 percent, while as a percentage of current expenditure, it ranges from 3 to 8 percent. Overall, for the four provinces combined, interest payments in 2010/11 accounted for 5 percent of current expenditure. Therefore, the current provincial debt levels appear to be relatively small and manageable.

Following the $18^{\text {th }}$ Amendment, the provinces have been given the powers to raise domestic or foreign loans on conditions indicated in clauses (3) and (4) of Article 167:

(3) A province may not, without the consent of the Federal Government, raise any loan if there is still outstanding any part of a loan made to the Province by the Federal government; or in respect of which guarantee has been given by the Federal government; and consent under this clause may be granted subject to such conditions, if any, as the Federal government may think fit to impose.

(4) A province may raise a domestic or international loan, or give guarantees on the security of the Provincial Consolidated Fund within such limits and subject to such conditions as may be specified by the National Economic Council.

To what extent is the relatively "hard budget constraint" that provincial governments face likely to be softened by these clauses? In 2010/11 and 2011/12, the provinces had recourse to substantially larger transfers under the $7^{\text {th }}$ NFC award and, therefore, did not feel the need to target have significantly higher borrowings. What will happen if the fiscal space diminishes in the coming years, especially in the lead-up to the next election in 2013 as the provincial governments embark on populist spending? The temptation to borrow may rise, especially from provincially owned commercial banks such as the Bank of Punjab, Sindh Bank, and the Bank of Khyber. How will the State Bank of Pakistan regulate such borrowing? Is there a need to set up some fiscal rules to ensure that provincial governments' debt is sustainable?

Given the low level of outstanding provincial debt, there is a case for enhancing the access of provincial governments to different sources of finance. This is important in view of their expanded responsibilities, 
including the need for capital-intensive investment in power generation (such as the development of the Thar coal reserves) and irrigation. However, it is important to ensure that subnational debt is sustainable if the provinces are to avoid problems of financial insolvency in the medium to long run, which might otherwise lead to a situation where the federal government has to engage in bail-out operations as 'lender of the last resort'. Excessive subnational borrowing could also jeopardize adherence to the country's macroeconomic and fiscal framework.

International experience is relevant in this area in terms of defining the limits and conditions for borrowing by subnational governments. As a consequence of debt crises faced by such governments, large consolidated (federal plus subnational) fiscal deficits, and large hidden and contingent liabilities, countries such as Brazil, Argentina, and India have developed safeguard mechanisms and fiscal rules for subnational governments to ensure the long-run sustainability of debt.

The provincial governments may have to deliberate on the case for enacting fiscal responsibility legislation, such as that by the federal government of Pakistan and the state governments of India. The key elements of the model draft legislation will need to quantify targets related to, for example, the following: (i) minimum level of revenue surplus as a percentage of revenue receipts, (ii) maximum level of net borrowing as a percentage of revenue receipts, (iii) ceiling on outstanding debt as a percentage of revenue receipts, and (iv) limit on the level of new guarantees. The first and second rules will ensure that provinces continue to generate enough revenue surpluses to finance their ADPs and that all borrowings are used to finance investment. The second and third rules will prevent outstanding debt from rising to unsustainable levels. The fourth rule will prevent excessive resort to off-budget commitments and thereby avoid the risk of large contingent liabilities on the provincial debt consolidated fund.

\section{Emerging Issues Related to the Delivery of Services}

The complexity of the $18^{\text {th }}$ Amendment is highlighted by the number of emerging issues relating to its implementation. We have already seen the intense public debate that surrounded the devolution of the HEC's functions, culminating in a stay order by the Supreme Court of Pakistan, preserving the status quo pending the amendment to the HEC Act.

The implementation commission headed by Senator Rabbani was mandated to complete the devolution process under the $18^{\text {th }}$ Amendment 
by $30^{\text {th }}$ June 2011. This was indeed a very ambitious target. The political leadership appears to have followed a "big bang" approach to quickly completing the process before potentially opposing forces-in the form of the federal bureaucracy and security establishment-could get organized and begin thwarting the move. This strategy has ensured relatively fast implementation but also runs the risk of inadequate preparation and mistakes in implementation, leading to some disruptions in the delivery of services down the road.

We highlight some of the key emerging issues below.

\subsection{Devolution of the Health Division}

The Health Division was devolved in the last phase (by 30th June 2011). However, no clear decisions have been made about the extent and nature of the transfer of these functions to the provinces. This is likely to be a complex issue since the division was responsible for diverse functions, including drug control as per the Drugs Act 1976. The law provides for a system of licensing for each manufacturing establishment and the registration of all finished drugs. Quality control is ensured through inspections and laboratory services. The law also controls drug prices in order to ensure the availability of basic drugs at reasonable prices while allowing competition.

Two serious issues emerge from the devolution of the Health Division.

1. Will the provinces have the capacity to rigorously perform the regulatory functions of licensing and drug registration? What will happens if one province follows a more liberal drug control policy than the others? Not only is this likely to have negative spillover effects on the other provinces, it may also lead to an overall loss of quality control. Will it be possible to introduce export controls from one province to another?

2. The Health Division has performed the drug price-fixing role relatively effectively so far. Here, too, one or more provinces may allow greater price escalation, perhaps in an effort to attract more manufacturing units into their respective jurisdictions. This will not only lead to a jump in the price level of medicines, but also to the suboptimal location of pharmaceutical concerns in the country. 


\subsection{Devolution of the Food and Agriculture Division}

The Ministry/Division of Food and Agriculture is responsible mainly for policy formulation, economic coordination, and planning with respect to food grains and agriculture. It has played an important role in national food security by procuring food grains from domestic sources or abroad, if necessary, for federal requirements or inter-provincial supplies. It also exercises import and export controls on food grains, stabilizes prices by fixing procurement/support prices, and issues prices nationally. It undertakes research on agricultural commodities, and is responsible for seed testing and certification, standardization, and the import of fertilizer, pesticides, and aerial sprays to meet provincial requirements.

Given the multitude of important tasks that it performs, there is a real threat that national food security may be jeopardized if the devolution to provincial governments is not managed carefully and rationally. In particular, the issues that emerge are as follows.

1. How will inter-provincial supplies of wheat to deficit provinces be managed? Will the private sector be assigned a bigger role in wheat procurement and marketing or will the Pakistan Agricultural Supplies and Storage Corporation be retained as an autonomous entity under some federal ministry (such as commerce)?

2. Import requirements (if any) for wheat must be determined early if supply shortages are to be avoided. Who will arrange this import? Will provinces import wheat directly or will the Trading Corporation of Pakistan continue to play the same role? Currently, the import of fertilizers is subsidized. How will it be imported post-devolution, and who will be responsible for financing the subsidy?

3. Procurement/support prices, especially for wheat, were fixed nationally on the recommendation of the Ministry of Food and Agriculture. In the future, will the individual provinces fix these prices and will free inter-provincial movement be allowed, or will the CCI set a common price?

4. Agricultural research is a case of a classical public good. If it is provincialized, then there is a clear danger of suboptimal allocations and outcomes. Pest control is another area where negative externalities could be conferred to other jurisdictions by a province that does not allocate enough resources to this function. 


\subsection{Devolution of Labor and Manpower Division}

This division was also devolved in the last phase. It performed functions broadly related to policy formulation in the areas of industrial relations, human resource planning, and employment promotion in coordination with the provincial governments. The key concern here is the operation of a national social security scheme for industrial workers and workers' welfare schemes at the federal level through the Employees OldAge Benefits Institution (EOBI) and the Workers' Welfare Fund (WWF), respectively.

The EOBI was constituted as an autonomous body under the Employees Old-Age Benefits Act 1976. Under this scheme, insured persons are entitled to receive benefits such as old-age pensions (following retirement), invalidity pensions (in cases of permanent disability), and survivors' pensions (in cases where the insured pensioner has expired). The minimum pension is PKR 3,000 per month. A contribution equal to 5 percent of minimum wages is paid by employers of all industrial and commercial organizations to which the act is applicable. Employees are expected to contribute 1 percent of minimum wages. As of May 2011, 52,936 employers and 4.7 million insured persons were registered, and benefits were being given to over 387,000 persons. The EOBI's total assets are estimated at over PKR 180 billion. It appears to be in a sound financial position, with an annual income-consisting of contributions and yields on investments - of PKR 27 billion while outflows in the form of benefits equal PKR 5 billion (2008).

Will the provincial governments accept the continuation of the EOBI as an autonomous national entity? Its large assets and relatively strong financial position may prove it an attractive institution for potential takeover by the provinces. If so, what will be the formula for distribution among the provinces? Will it be linked to the NFC revenue-sharing formula or to percentage shares in contributions or to shares in pension payments? If social security for workers is provincialized, what are the implications of any variation in benefits across provinces?

Similar problems arise in the context of the WWF. Accruals to the fund are in the form of annual contributions by industrial establishments (with an income exceeding PKR 100,000) equivalent to 2 percent of income. In 2009/10, total collection under this head was PKR 4 billion. The contributions can be used to finance projects for workers' benefits, such as housing, schools, and clinics, etc. 
Like the EOBI, the WWF is an attractive prospect for provincial takeover. If so, we run into the same problems concerning the sharing of assets, liabilities, and annual contributions. Sindh is inclined to argue that these should be shared on the basis of the origin of the contributions since a large proportion of the head offices of establishments are located in the province. Punjab, on the other hand, will present the case that sharing should be on the basis of the distribution of workers. Another problem that is likely to surface is that WWF contributions have hitherto gone into the federal consolidated fund (as part of direct tax revenues) and not been transferred fully to the WWF.

\subsection{Sharing Natural Resources}

The $18^{\text {th }}$ Amendment has inserted the following in Article 172, Clause 3:

Subject to the existing commitments and obligations, mineral oil and natural gas within the Province or the territorial water adjacent thereto shall vest jointly and equally in the Province and the Federal Government.

The question is whether this clause implies the following:

1. The authority to grant concessions for exploration of oil and gas reserves now rests with both the federal and provincial governments combined. Previously, it resided with the federal government alone.

2. As highlighted above, will the provincial governments have a 50 percent share in ownership of the government equity of corporations in the oil and gas sector, such as PPL, SNGPL, SSGCL, and OGDC? If so, will they be entitled to receive 50 percent of the dividend income that is currently received by the federal government? There is sizeable incentive for provincial governments to make this claim.

Another latent issue concerns Article 158, which states:

The Province in which a well-head of natural gas is situated shall have precedence over other parts of Pakistan in meeting the requirements from that well-head, subject to commitments and obligations as on the commencing day.

Now that there is a pronounced shortage of gas in the country and Sindh is the major province producing gas at present, there is a perception 
that Punjab, in particular, is being starved of gas supplies while Sindh's demand is given preference. Punjab's chief minister has already indicated that there will be public protests if discrimination in gas supplies to the province continues. There is, perhaps, a case for the deregulation of gas prices such that the allocation promotes economic efficiency.

\subsection{The $18^{\text {th }}$ Amendment and Local Governments}

Local governments have gained formal recognition in the Constitution after the $18^{\text {th }}$ Amendment with the following clause:

\section{Clause 140 A}

(1) Each Province shall, by law, establish a local government system and devolve political, administrative and financial responsibility and authority to the elected representatives of the local governments.

(2) Elections to the local governments shall be held by the Election Commission of Pakistan.

Despite this recognition, developments on the ground have been adverse, following the return to democracy. The natural expectation was that, with the transfer of more resources and functions to the provincial governments, they would, in turn, be willing to empower local governments and transfer more funds and functions to them. Instead, the opposite has happened: Elected local governments have been dissolved and interim administrators appointed from the bureaucracy. Elections to the local councils have been delayed despite a Supreme Court decision. In Punjab, a new local government ordinance has been finalized with radical changes in relation to the Devolution Plan of 2001. There appears to be a reversion essentially to the Local Government Ordinance 1979. District governments are being abolished and it is proposed that the old municipal structure be reintroduced. Simultaneously, in Punjab, certain functions such as secondary education, curative health, and public safety are being taken back from the local governments and made the responsibility of the provincial government. The process of decentralization appears to have stopped at the intermediate level of the provincial governments, and has not moved any closer to the people through the strengthening of local governments. In Sindh, there is an ongoing tussle between the two major political parties on the extent of devolution to local governments. 
There is no doubt that the $18^{\text {th }}$ Amendment is a landmark achievement and that, in the short run, it has politically empowered the provinces, thereby strengthening the federation. But in the medium term, emerging issues of the type described above may surface, and could introduce new problems for the federation. Significant work needs to be undertaken, both at the technical level and through consensus building, to ensure that these issues are rationally and amicably resolved to ensure the smooth delivery of services.

\section{Conclusion}

This article has demonstrated that the $7^{\text {th }}$ NFC award and the $18^{\text {th }}$ Amendment to the Constitution are both key developments that have strengthened the autonomy of the federating units in Pakistan and proven landmark achievements of the democratically elected government. However, both come with caveats.

The 7th NFC Award has empowered the provinces by increasing their access to financial resources, but it also stands in danger of increasing the consolidated fiscal deficit. To make the change more meaningful and effective, both the federal and provincial governments must enhance their level of fiscal effort. The federal government will simultaneously need to rationalize and streamline its expenditures. The provinces must avoid wasteful recurrent spending and augment their development activities while developing an effective development framework to maximize gains from additional resources.

The $18^{\text {th }}$ Amendment has the potential to change the structure of governance in Pakistan, but its manner of implementation has meant that effective decentralization has been largely postponed or at least partially rolled back in some areas. For devolution to work in Pakistan, the financing and delivery of devolved services at the provincial level will have to be effectively organized and managed. 


\section{References}

Balochistan, Finance Department. (n.d.). Annual budget statement. Quetta, Pakistan: Author.

Braun, M., \& Tommasi, M. (2004). Subnational fiscal rules: A game theoretic approach. In G. Kopits (Ed.), Rules-based fiscal policy in emerging markets: Background, analysis and prospects. New York, NY: Palgrave.

Corbacho, A., \& Schwartz, G. (2007). Fiscal responsibility laws. In M. S. Kumar \& T. Terr-Minassian (Eds.), Promoting fiscal discipline. Washington, DC: International Monetary Fund.

Crivelli, E., \& Shah, A. (2009). Fiscal rules at the local level (Mimeo).

Institute of Public Policy. (2010a). State of the economy: Pulling back from the abyss. Lahore, Pakistan: Author.

Institute of Public Policy. (2010b). VAT on services. Lahore, Pakistan: Author.

Institute of Public Policy. (2011). State of the economy: Devolution in Pakistan. Lahore, Pakistan: Author.

Khyber Pakhtunkhwa, Finance Department. (n.d.). Annual budget statement. Peshawar, Pakistan: Author.

Liu, L., \& Waibel, M. (2008). Subnational borrowing, insolvency and regulation. In A. Shah (Ed.), Macro-federalism and local finance. Washington, DC: World Bank.

Pasha, H. A. (2011). From stagflation to growth. The News, Money matters.

Pasha, H. A., Pasha, A. G., \& Imran, M. (in press). Behavioral consequences of the NFC Award. Pakistan Development Review.

Punjab, Finance Department. (n.d.). Annual budget statement. Lahore, Pakistan: Author.

Sindh, Finance Department. (n.d.). Annual budget statement. Karachi, Pakistan: Author. 